\title{
MANAJEMEN PROGRAM PUSAT INFORMASI DAN KONSELING REMAJA (PIK-R) DI SMA NEGERI 1 PEKANBARU
}

\author{
Wahyuningsih Budi Astuti ${ }^{(1)}$ \\ Zulfan Saam ${ }^{(2)}$ \\ Isjoni ${ }^{(3)}$ \\ ${ }^{1)}$ Post Graduate Student of Riau University \\ ${ }^{2)}$ Lecturer of Education Management Study Programme PPs University of Riau \\ ${ }^{3}$ Lecturer of Education Management Study Programme PPs University of Riau
}

\begin{abstract}
The aim of this research is how management of program the information center and counseling youth at SMAN 1 Pekanbaru with subfokus are: (1) Achievement of vision and mission implementation of program the information center and counseling youth at SMAN 1 Pekanbaru (2) Planning of program the information center and counseling youth at SMAN 1 Pekanbaru (3) Organizing of program the information center and counseling youth at SMAN 1 Pekanbaru (4) Implementation of program the information center and counseling youth at SMAN 1 Pekanbaru (5) Supervision of program the information center and counseling youth at SMAN 1 Pekanbaru (6) The result of program the information center and counseling youth at SMAN 1 Pekanbaru. The approach of this research is qualitative gotten from respondents with data collection technique through documentation, observation, and in-depth interview. Further data analysis through data reduction, display data, conclusion and verification. The results showed that (1) Achievement of vision and mission implementation of program the information center and counseling youth at SMAN 1 Pekanbaru is categorized sufficient because it has fulfilled 3 aspects of 5 aspects from the objective standard (2) Planning of program the information center and counseling youth at SMAN 1 Pekanbaru is categorized good because it has fulfilled 4 aspects of the 5 aspects from the objective standard (3) The organization of program the information center and counseling youth at SMAN 1 Pekanbaru is categorized very well because it has fulfilled 5 aspects of 5 aspects from the objective standard (4) Implementation of program the information center and counseling youth at SMAN 1 Pekanbaru is categorized well because it has fulfilled 4 aspects of 5 aspects from the objective standard (5) Supervision of program the information center and counseling youth at SMAN 1 Pekanbaru is categorized sufficient because it has fulfilled 3 aspects from 5 aspects from the objective standard (6) The result of program the information center and counseling youth in SMAN 1 Pekanbaru is categorized less because it has fulfilled 2 aspects of 5 aspects from objective standard.
\end{abstract}

Keywords: Management, PIK-R, SMAN 1 Pekanbaru School

ABSTRAK: Tujuan penelitian ini adalah bagaimana manajemen program pusat informasi dan konseling remaja di SMAN 1 Pekanbaru dengan subfokus yaitu: (1) Pencapaian visi dan pelaksanaan misi Program Pusat Informasi dan Konseling Remaja di SMAN 1 Pekanbaru (2) Perencanaan Program Pusat Informasi dan konseling remaja di SMAN 1 Pekanbaru (3) Pengorganisasian Program Pusat Informasi dan Konseling Remaja di SMAN 1 Pekanbaru (4) Pelaksanaan Program Pusat Informasi dan Konseling Remaja di SMAN 1 Pekanbaru (5) Pengawasan Program Pusat Informasi dan Konseling Remaja di SMAN 1 Pekanbaru (6) Hasil Program Pusat Informasi dan Konseling Remaja di SMAN 1 Pekanbaru. Pendekatan 
penelitian ini ialah kualitatif yang digali dari responden dengan teknik pengumpulan data melalui dokumentasi, observasi, dan wawancara mendalam. Selanjutnya analisis data melalui reduksi data, display data serta kesimpulan dan verifikasi. Hasil penelitian menunjukkan bahwa (1) Pencapaian visi dan pelaksanaan misi Program Pusat Informasi dan Konseling Remaja di SMAN 1 Pekanbaru dikategorikan sedang karena telah memenuhi 3 aspek dari 5 aspek standar objektif (2) Perencanaan Program Pusat Informasi dan Konseling Remaja di SMAN 1 Pekanbaru dikategorikan baik karena telah memenuhi 4 aspek dari 5 aspek standar objektif (3) Pengorganisasian Program Pusat Informasi dan Konseling Remaja di SMAN 1 Pekanbaru dikategorikan sangat baik karena telah memenuhi 5 aspek dari 5 aspek standar objektif (4) Pelaksanaan Program Pusat Informasi dan Konseling Remaja di SMAN 1 Pekanbaru dikategorikan baik karena telah memenuhi 4 aspek dari 5 aspek standar objektif (5) Pengawasan Program Pusat Informasi dan Konseling Remaja di SMAN 1 Pekanbaru dikategorikan sedang karena telah memenuhi 3 aspek dari 5 aspek standar objektif (6) Hasil Program Pusat Informasi dan Konseling Remaja di SMAN 1 Pekanbaru dikategorikan kurang karena hanya memenuhi 2 aspek dari 5 aspek standar objektif.

Kata kunci: Manajemen, PIK-R, Sekolah SMAN 1 Pekanbaru

\section{PENDAHULUAN}

Jumlah penduduk yang besar merupakan aset yang utama seandainya diimbangi dengan kualitas yang baik. Namun pada kenyataannya kualitas SDM yang dinilai melalui "Human Development Indek (HDI)” atau Indek pembangunan manusia(IPM) oleh UNDP (united nations development programme) menempatkan Indonesia pada urutan 108 dari 189 negara (sensus penduduk tahun 2013). Tantangan terbesar dalam upaya peningkatan kualitas manusia Indonesia dilihat dari IPM tersebut adalah masalah kesehatan, pendidikan, dan kesejahteraan penduduk.

Jumlah remaja (usia 10-24 tahun) mencapai lebih dari 66.0 juta (sensus penduduk 2015), Jumlah penduduk Indonesia sampai tahun 2019 diprediksi sebesar 268,1 juta apa bila laju pertumbuhan penduduk tetap diangka 1,49 persen.

Jumlah yang sangat besar tersebut adalah potensi yang memerlukan pengelolaan atau manajemen yang terencana, sistimatis dan terstuktur agar dapat dimanfaatkan menjadi modal pembangunan kedepan manajemen yang bersifat umum dan meliputi keseluruhan proses manajerial.

Membangun dan membina remaja tidak hanya menyiapkan masa depannya saja akan tetapi juga menjaga mereka agar terhindar dari resiko dan permasalahan yang dihadapi mereka saat ini. Resiko dan permasalahan yang dihadapi diantaranya, perilaku seks pada remaja hasil penelitian menunjukkan masih banyak remaja yang aktif secara seksual diluar nikah. Berdasarkan data SKRRI ( Survei Kesehatan Reproduksi Remaja Indonesia) tahun 2003 dan 2007, terdapat kecendrungan kenaikan proporsi remaja usia 15-24 tahun aktif secara seksual pada tahun 2003 terutama pada kalangan lakilaki yaitu $5 \%$ dan pada perempuan $1 \%$, tahun 2007 menjadi $6 \%$ pada laki-laki dan $1 \%$ pada perempuan. Menurut data SDKI (Survei Demografi dan Kesehatan Indonesia) 2012, angka tersebut mengalami kenaikan menjadi 8,3\% untuk laki-laki sedangkan perempuan menunjukkan kecendrungan yang stabil.

Pengguna NAPZA (Narkotika, Alkohol, Psikotropika dan Zat Adiktif) pada remaja dari data BNN (Badan Narkotika Nasional) tahun 2013 menunjukkan bahwa 22\% dari 4 juta penduduk Indonesia penyalahgunaan narkoba atau sekitar 880 ribu penyalahgunaan NAPZA adalah pelajar dan remaja/mahasiswa. Berdasarkan data dan kondisi diatas, menunjukkan betapa banyaknyanya jumlah remaja Indonesia yang akan terganggu kesempatannya untuk melanjutkan sekolah 
Pendidikan adalah faktor penting untuk mewujudkan sumber daya manusia (SDM) yang berkualitas. Pendidikan merupakan bentuk usaha manusia untuk membina kepribadiannya sesuai dengan nilai-nilai yang ada dalam masyarakat dan kebudayaan. Dalam perkembangannya istilah pendidikan berarti bimbingan atau pertolongan yang diberikan dengan sengaja oleh seseorang atau sekelompok orang untuk mendewasakan atau mencapai tingkat penghidupan yang lebih tinggi dalam segala hal yang tentunya bersifat positif dan kontinyu. Hal ini berarti pendidikan merupakan suatu proses panjang dalam rangka meningkatkan kualitas hidup manusia di segala aspek dan menjalani kehidupan yang bercita-cita dan bertujuan pasti.

Dalam UU Sisdiknas Nomor 20 Tahun 2003 pasal 3 pendidikan Nasional berfungsi mengembangkan kemampuan dan membentuk watak serta peradapan bangsa yang bermartabat dalam rangka mencerdaskan kehidupan bangsa, bertujuan untuk berkembangnya potensi peserta didik agar menjadi manusia yang beriman dan bertakwa kepada tuhan yang maha esa, berakhlak mulia,sehat, berilmu, cakap, kreatif, mandiri dan menjadi warga Negara yang demokratis serta bertanggung jawab.

Untuk membentuk manusia yang disebutkan dalam UU Sisdiknas Nomor 20 tahun 2003 pasal 3 salah satunya melalui pendidikan formal. Dalam pendidikan formal ada kegiatan intra dan ada ekstrakurikuler yang salah satunya Program Informasi dan Konseling Remaja atau dikenal PIK-R yang bertujuan untuk pengembangan diri. PIK-R bukan merupakan mata pelajaran yang harus diasuh oleh guru. PIK$\mathrm{R}$ bertujuan memberikan kesempatan kepada peserta didik untuk mengembankan diri sesuai dengan kebutuhan, bakat, dan minat setiap peserta didik sesuai dengan kondisi sekolah. Kegiatan pengembangan diri dibimbing oleh konselor, guru, atau tenaga kependidikan yang dapat dilakukan dalam bentuk kegiatan ekstrakurikuler. Kegiatan pengembangan diri dilakukan melalui kegiatan pelayanan konseling yang berkenan dengan masalah diri pribadi dan kehidupan sosial, belajar, dan pengembangan karir peserta didik.

Dalam merespon permasalahan remaja tersebut perlu menetapkan pedoman pengelolaan Pusat Informasi dan kependudukan dan keluarga berencana Nasional sebagaimana diatur dalam perundang-undangan. Untuk membantu dan membina remaja menyiapkan masa depannya terutama dalam perencanaan kehidupan berkeluarga serta merespon permasalahanpermasalahan yang terjadi pada remaja, pengelolaan Pusat Informasi kependudukan dan keluarga berencana dibutuhkan manajemen yang handal. Menurut T. Hani Handoko ( 1999 : 3) Manajemen dibutuhkan untuk semua tipe kegiatan dan manajemen dibutuhkan untuk mencapai suatu tujuan bersama, seperti salah satunya organisasi

BKKBN (Badan Kependudukan Keluarga Berncana Nasional) sesuai dengan amanat UU No. 52 tahun 2009 mengembangkan program Program Generasi Berencana yang disingkat Menjadi GenRe. Program GenRe adalah program yang dikembangkan dalam rangka menyiapkan kehidupan berkeluarga bagi remaja sehingga mereka mampu melangsungkan jenjang pendidikan secara terencana, berkarir dalam pekerjaan secara terencana, serta menikah dengan penuh perencanaan sesuai siklus kesehatan reproduksi.

Program GenRe ditujukan kepada remaja melalui wadah PIK Remaja dan keluarga yang memiliki remaja melalui wadah Bina Keluarga Remaja (BKR).PIK remaja adalah salah satu wadah yang dikembangkan dalam program GenRe, yang dikelola dari, oleh dan untuk remaja guna memberikan pelayanan informasi dan konseling yang cukup dan benar tentang penyiapan kehidupan berkeluarga bagi remaja. Masa remaja sangat erat kaitannya dengan perkembangan psikis pada periode yang dikenal sebagai pubertas serta diiringi dengan perkembangan seksual. Kondisi ini menyebabkan remaja menjadi rentan terhadap masalah-masalah perilaku berisiko, seperti melakukan hubungan seks sebelum menikah 
menyalaggunakan NAPZA, yang keduanya dapat membawa resiko terhadap penularan HIV dan AIDS. Kompleksitas permasalahan remaja tersebut perlu mendapat perhatian secara terusmenerus guna menjamin kualitas gererasi mendatang

Di bentuknya ekstrakulikuler PIK- R SMA Negeri 1 Pekanbaru adalah untuk membantu remaja di SMA Negeri 1 Pekanbaru guna mendapatkan informasi seputar masalah kesehatan remaja yang baik, sehingga pada akhirnya terwujud remaja yang terhindar dari free sex, NAPZA dan HIV / AIDS serta pergaulan bebas lainnya.

Untuk terlaksananya tujuan ini maka melalui ekstrakulikuler ini direkrut siswa-siswi yang berkarakter, berkomitmen dan kompeten serta punya hati untuk melayani rekan remajanya yang membutuhkan informasi dan konseling tentang permasalahan khususnya yang dihadapi siswa seusianya mereka, oleh sebab itu setiap pelaksanaan PIK-R telah dilengkapi terlebih dahulu dengan materi yang berhubungan dengan permasalahan yang dihadapi siswa seusianya yang mungkin punya permasalah remaja serta keterampilan dalam memberikan pelayanan yang optimal bagi cliennya.

PIK-R remaja dikembangkan melalui 3 (tiga) tahapan yaitu tahap tumbuh, tegak, dan tegar. Proses pengembangan dan pengelolaan masing-masing tahapan tersebut didasarkan pada 1) materi dan pesan yang diberikan, 2) ciri kegiatan yang dilakukan, 3) dukungan dan jaringan yang dimiliki. PIK-R SMA Negeri 1 Pekanbaru masih dalam tahap tumbuh, sehingga yang menjadi sasaran yang hendak dicapai adalah semua siswa-siswai SMA Negeri 1 yang memili komitmen untuk menjadi pendidik sebaya dan konselor sebaya dalam melayani teman seusia mereka, yang memiki permasalahan seputar dirinya yang tidak dapat dipecahkan nya sendiri. Kegiatan yang dilakukan pada tahap ini adalah membentuk aktifitas bersifat penyadaran dengan menggunakan media cetak ( majalah dinding, leaflet, poster dll ) dalam pemberian infornasi dan melakukan pencatatan dan pelaporan rutin untuk melakukan peningkatan layanan dimasa datang.

Kegiatan Pusat Informasi dan Konseling Remaja (PIK-R) SMAN 1Pekanbaru didirikan 28 Agustus 2013 dalam proses tahap tumbuh, yang merupakan tahap peningkatan kemampuan dan kemauan positif remaja tentang TRIAD KRR yang artinya tiga resiko yang dihadapi remaja yaitu resiko yang berkaitan dengan NAPZA, HIV dan AIDS. Lamanya proses pembinaan remaja pada kegiatan PIK-R dari tahap tumbuh menuju ketahapan tegak seharusnya dibutuhkan waktu 1 tahun namun yang terjadi di di SMAN 1 Pekanbaru menunjukkan bahwa proses pembinaan remaja dari tumbuh ketahapan tegak membutuhkan waktu lebih lama dari target BKKBN yaitu sekitar lebih 3 tahun, lamanya pembinaan remaja dapat berpengaruh terhadap penanganan permasalahan remaja menjadi lambat.

Pentingnya pengetahuan kesehatan reproduksi remaja tidak diimbangi dengan pengelolaan PIK Remaja yang baik di sekolah tentu akan mempengaruhi pelayanan, PIK-R SMAN 1 pekanbaru dilihat dari buka layanan untuk konseling dalam satu minggu hanya ada satu kali bahkan tidak ada buka layanan, hal ini dapat dilihat dari catatan buku layanan konseling idealnya buka layanan lebih dari 4 kali dalam seminggu ( BKKBN). Pelayanan konseling bagi remaja merupakan tugas PIK-R untuk membantu masalah yang muncul bagi remaja yang ada di sekolah, jadi pemberian layanan konseling belum berjalan dengan baik

Berdasarkan fenomena-fenomena yang telah dikemukakan diatas, maka penulis tertarik untuk melakukan penelitian dengan judul “ Manajemen Program Pusat Informasi dan Konseling Remaja (PIK-R) di SMA Negeri 1 Pekanbaru”.

Manajemen berasal dari bahasa latin manus yang berarti tangan dan agree (melakukan). Kata-kata itu digabung menjadi manager yang artinya menangani, managere diterjemahkan kebahasa inggris to manage (kata kerja), dan manager untuk orang yang 
melakukannya. Menurut Husaini Usman (2013 : 5) Management diterjemahkan kebahasa Indonesia menjadi manajemen (pengelolaan). Manajemen dalam arti luas adalah perencanaan, pelaksanaan, dan pengawasan (P3) sumber daya organisasi untuk mencapai tujuan secara efektif dan efisien. Manajemen dalam arti sempit adalah manajemen sekolah/madrasah yang meliputi : perencanaan program sekolah/madrasah, pelaksanaan program sekolah/madrasah , kepemimpinan kepala sekolah/madrasah, pengawas/evaluasi, dan sistim informasi sekolah/ madrasah.

Planning adalah proses mendefinisikan tujuan organisasi, membuat strategi untuk mencapai tujuan itu dan mengembangkan rencana aktivitas kerja dalam sebuah organisasi. Perencanaan merupakan proses yang penting dari segala bentuk fungsi manajemen, karena tanpa adanya perencanaan semua fungsi-fungsi lainnya tidak akan dapat berjalan.

Dalam perencanaan terdapat beberapa faktor dalam planning yang patut untuk dipertimbangkan salah satu teori dan prinsp dalam ilmu manajemen yang dikemukakan oleh ahli manajemen George Robert Terry yaitu Specific berarti sebuah perencanaan harus jelas apa maksud dan tujuanya beserta ruang lingkupnya. Measurable yaitu suatu tingkat keberhasilan yang harus dapat diukur dari program kerja dan rencana yang dibuat. Achievable yaitu sesuatu tersebut bisa tercapai dan diwujudkan, bukan hanya sekedar fiktif dan khayalan belaka. Realistic yaitu sesuatu yang sesuai dengan kemampuan dan sumber daya yang ada, harus seimbang tetapi tetap ada tantangan didalamnya.Time yaitu ada batas waktu yang jelas, sehingga bisa dinilai dan dievaluasi.

Perencanaan menurut Akdon (2011:103) mempertimbangkan berbagai realitas yang dihadapi sebelum merumuskan perencanaan pendidikan merupakan hal yang amat penting karena perencanaan pendidikan akan berkaitan dengan fasilitas sarana dan prasarana yang telah dimiliki atau yang belum dimiliki. Dengan demikian, perencanaan pendidikan yang tidak proporsional akan mempersulit terlaksananya kegiatan pendidikan dengan cara yang efektif dan efisien.

Pengorganisasian ( Organizing ) adalah fungsi kedua dalam Manajemen Organizing adalah proses kegiatan dalam menyusun struktur organisasi sesuai dengan tujuan-tujuan, sumbersumber dan lingkungannya. Dengan demikian, hasil dari pengorganisasian itu berupa struktur organisasi. setiap tujuan disebuah organisasi pasti ingin dicapai, dan untuk meraih hal tersebut, pengorganisasian sangat berperan penting. Dalam sebuah perusahaan, pengorganisasian biasanya disusun dalam bentuk badan organisasi atau struktur organisasi, setelah itu baru dipecah menjadi beberapa jabatan. Disinilah letak salah satu prinsip Manajemen yang membagi setiap tugas dan tanggung jawab dalam sebuah perusahaan yang dibebankan pada semua anggota menurut skill dan kemampuan individu.

Organizing menurut wibowo (2012 :13) merupakan tanggung jawab manajer untuk mendesain stuktur organisasi dan mengatur pembagian pekerjaan. Termasuk mempertimbangkan apa tugas yang harus dilakukan, siapa melakukan, bagaimana tugas dikelompokkan, siapa melapor siapa, dan dimana keputusan dibuat. Organizing merupakan persiapan sebelum pekerjaan sebenarnya dilakukan.

(Pelaksanaan) adalah suatu tindakan yang mengusahakan agar semua perencanaan dan tujuan perusahaan bisa terwujud dengan baik dan seperti yang diharapkan. Jadi pelaksanaan merupakan suatu upaya yang menggerakkan orang-orang untuk mau bekerja dengan sendirinya dan dengan kesadaran yang besar demi mengabulkan seluruh cita-cita perusahaan dengan dan secara efektif. Perencanaan dan pengorganisasian akan berjalan kurang baik jika tidak disertai dengan pelaksanaan. Oleh karena itu, sangat dibutuhkan sekali bentuk nyata dari kerja keras, kerjasama dan kerja nyata didalamnya. Pengoptimalan seluruh sumber daya manusia yang ada juga sangat penting, terutama ditujukan untuk mencapai visi, misi dan Planning 
yang telah diterapkan. Dalam poin ini, semua sumber daya manusia yang ada harus bekerja sesuai dengan tugas yang dibebankan, fungsi serta peran dan kompetensi dari masing-masing untuk mencapai tujuan organisasi.

Actuating munurut Wibowo ( 2012 : 14) adalah berkenaan dengan fungsi manajer untuk menjalankan tindakan dan melaksanakan pekerjaan yang diperlukan untuk mencapai tujuan yang ingin dicapai oleh organisasi. Actuating merupakan implementasi dari apa yang direncanakan dalam fungsi planning dengan memanfaatkan persiapan yang sudah dilakukan dalam organisasi

Menurut Wibowo (2012 : 14) Controling merupakan aktifitas yang meyakinkan bahwa semua hal berjalan seperti seharusnya dan memonitor kinerja organisasi. Kinerja actual harus dibandingkan dengan tujuan yang ditetapkan sebelumnya. Jika terdapat deviasi signifikan, dilakukan koreksi dan dikembalikan kejalur yang tepat. Dengan demikian, controling melakukan koreksi terhadap pelaksanaan dan untuk mengetahui apakah tujuan dapat dicapai.

Menurut Elizabeth B. Hurlock ( 2002 : 206) istilah adolescence atau remaja berasal dari kata latin (adolescere) (kata bendanya, adolescentia yang berarti remaja) yang berarti “tumbuh” atau “tumbuh menjadi dewasa”. Istilah adolescence, seperti yang dipergunakan saat ini, mempunyai arti yang lebih luas, mencakup kematangan mental, emosional, sosisl, dan fisik. Pandangan ini diungkapkan oleh Piaget dengan mengatakan: secara psikologis, masa remaja adalah usia dimana individu berintegrasi dengan masyarakat dewasa, usia dimana anak tidak lagi merasa dibawah tingkat orang-orang yang lebih tua melainkan berada dalam tingkatan yang sama, sekurang kurangnya dalam masalah hak.

Menurut BKKBN ( 2012 : 1) Tahun 2010 jumlah remaja umur 10-24 tahun sangat besar yaitu sekitar 64 juta atau 27,6\% dari jumlah Penduduk Indonesia sebanyak 237,6 juta jiwa (Sensus Penduduk, 2010) dan tahun 2015 jumlah penduduk Indonesia diperkirakan mencapai 255 juta jiwa . Melihat jumlahnya yang sangat besar, maka remaja sebagai generasi penerus bangsa perlu dipersiapkan menjadi manusia yang sehat secara jasmani, rohani, mental dan spiritual. Faktanya, berbagai penelitian menunjukkan bahwa remaja mempunyai permasalahan yang sangat kompleks seiring dengan masa transisi yang dialami remaja. Masalah yang menonjol dikalangan remaja yaitu permasalahan seputar TRIAD KRR (Tiga resiko yang dihadapi oleh remaja, yaitu resiko yang berkaitan denagan seksualitas, Napza, HIV dan AIDS ).

PIK Remaja/Mahasiswa adaIah satah satu wadah yang dikembangkan dalam program GenRe, yang dikelola dari, oleh dan untuk Remaja/Mahasiswa guna memberikan pelayanan informasi dan konseling tentang pendewasaan usia perkawinan, delapan fungsi keluarga, TRIAD KRR (seksualitas, HIV dan AIDS serta Napza), keterampilan hidup (life skills), gender dan keterampilan advokasi dan KIE (Komunikasi Informasi dan Edukasi). Keberadaan dan peranan PIK-R/M dilingkungan Remaja/Mahasiswa sangat penting artinya dalam membantu Remaja/ Mahasiswa untuk memperoleh informasi dan pelayanan konseling yang cukup dan benar tentang penyiapan kehidupan berkeluarga bagi Remaja/Mahasiswa. Untuk meningkatkan pengelolaan dan pelayanan PIK-R/M maka perlu adanya pedoman sebagai acuan bagi pengelola program dan pengelola PIK-R/M. Untuk itu disusunlah buku pedoman yang standar dan dapat digunakan oleh pihak-pihak yang memerlukan.

\section{METODOLOGI PENELITIAN}

Penelitian ini dilaksanakan di SMA Negeri 1 Kota Pekanbaru yang berlokasi di Sultan Syarif Qasim No. 159 Pekanbaru. Penelitian ini dilakukan penulis mulai bulan februari sampai akhir April 2017.

\section{A. Teknik dan Prosedur Pengumpulan Data}

Data Primer dalam penelitian ini dikumpulkan dengan wawancara dan observasi. Wawancara dilakukan dengan menggunakan pedoman wawancara. Informan inti adalah kepada kepala sekolah, Guru BK, guru pembina PIK-R, dan siswa di SMA Negeri 1 Pekanbaru, 
sebagai informan kontrol adalah kepala sekolah dan guru bimbingan koseling (BK).

Disamping wawancara, dalam pengumpulan data primer juga digunakan observasi peneliti menggunakan guide (pedoman) observasi. Studi dokumentasi juga dilakukan guna memperoleh data sekunder yang diperlukan dalam penelitian ini.

\section{A. Prosedur Analisis Data}

Dalam penelitian kualitatif Burhan bungin (2007 : 150) dikenal ada dua strategi analisis data yang sering digunakan bersama-sama atau secara tepisah yaitu model strategi analisis deskriptif kualitatif dan atau model strategi analisis verivikatif. Kedua model analisis ini memberikan gambaran bagaimana alur logika anaisis data penelitian kualitatif sekaligus memberi masukan terhadap bagaimana teknik analisis data data digunakan. Analisis data dalam penelitian kualitatif dilakukan sejak sebelum memasuki lapangan, selama dilapangan, dan setelah selesai dilapangan. Nasution (1988) menyatakan “Analisis telah mulai sejak merumuskan dan menjelaskan masalah, sebelum terjun kelapangan, dan berlangsung terus sampai penulisan hasil penelitian. Analisi data menjadi pegangan bagi penelitian selanjutnya sampai jika mungkin, teori yang grounded. Dalam penelitian kualitatif, analisis data lebih difokuskan selama proses dilapangan bersamaan dengan pengumpulan data.

Menurut Mohamad Ali dan Muhammad Asrori (2014: 288) langkah-langkah yang dilakukan dalam analisis data adalah sebagai berikut:

\section{Reduksi data}

Pada langkah reduksi data melakukan seleksi data, memfokuskan data pada permasalahaan yang dikaji, melakukan upaya penyederhanaan, melakukan Abstraksi, dan melakukan transformasi. Hal ini berarti dalam menempuh langkah ini penelitimemilih mana yang bersifat kesan pribadi, dan kesan-kesan pribadi itu dieliminasi dari proses analisis. Selain itu, dalam melakukan seleksi dilakukan kategori antara data yang penting dan data kurang penting, mengategorikan ini semata-mata dimaksudkan untuk tujuan memperkuat tafsiran terhadaphasil analisis data.

\section{Display Data}

Display data adalah langkah mengorganisasikan data dalam suatu tatanan informasi yang padat atau kaya makna sehingga dengan mudah dibuat kesimpulan. Display data biasanya dibuat dalam bentuk cerita atau teks.Display ini disusun dengan sebaik-baiknya sehingga menjadikannya sebagai jalan untuk menuju jalan pembuatan kesimpulan.

\section{Kesimpulan dan Verifikasi}

Berdasarkan hasil analisis data, melalui langkah reduksi data atau display data, langkah terakhir adalah menarik kesimpulan dan melakukan verifikasi terhadap kesimpulan yang dibuat. Kesimpulan yang dibuat adalah jawaban terhadap masalah riset. Akan tetapi, sebaikbaiknya isi kesimpulan dengan keadaan yang sebenarnya, dalam arti valid atau tidaknya kesimpulan dibuat, perlu diverifikasi. Verifikasi adalah upaya membuktikan kembali benar atau tidaknya kesimpulan yang dibuat. Atau sesuai tidaknya kesimpulan dengan kenyataan.

\section{B. Pemeriksaan Keabsahan data}

Menurut Sugiono (2013 : 270) Keabsahan atau kesahihan data harus dilakukan agar data yang diperoleh dapat dipertanggung jawabkan. Pelaksanaan teknik pemeriksaan didasarkan atas sejumlah kriteria tertentu. Ada empat kriteria yang digunakan, yaitu uji Credibility (Validityas interbal), transferability ( Validitas eksternal), dependability ( reliabilitas), dan confirmability (obyektivitas).

\section{Kepercayaan (credibility)}

Uji kredibilitas data atau kepecayaan terhadap data hasil penelitian kualitatif antara lain dilakukan dengan perpanjangan pengamatan, peningkatan ketekunan dalam penelitian, triangulasi, diskusi dengan teman sejawat, analisis kasus negatif, dan membercheck, 
Menurut Hamid Darmadi (2014: 294) cara memperoleh tingkat kepercayaan hasil penelitian, yaitu:

a. Memperpanjang masa pengamatan lapangan, memungkinkan peningkatan derajat kepercayaan data yang dikumpulkan, bisa mempelajari kebudayaan dan dapat menguji informasi dari responden, dan untuk membangun kepercayaan para responden terhadap peneliti dan juga kepercayaan diri peneliti sendiri.

b. Pengamatan yang terus menerus, untuk menemukan ciri-ciri dan unsur-unsur dalam situasi yang sangat relevan dengan persoalan atau isu yang sedang diteliti, serta memusatkan diri pada hal-hal tersebut secara rinci.

c. Triangulasi, pemeriksaan keabsahan data yang memanfaatkan sesuatu yang lain diluar data untuk keperluan pengecekan atau sebagai pembanding terhadap data tersebut.

d. Peer debriefing (membicarakannya dengan orang lain) yaitu mengekspos hasil sementara atau hasil akhir yang diperoleh dalam bentuk diskusi analitik dengan rekan-rekan sejawat.

e. Mengadakan member check yaitu dengan menguji kemungkinan dugaan-dugaan yang berbeda dan mengembangkan pengujianpengujian untuk mengecek analisis, dengan mengaplikasikannya pada data,serta dengan mengajukan pertanyaan-pertanyaan tentang data.

\section{Keteralihan (transferability)}

Agar orang lain dapat memahami hasil penelitian kualitatif sehingga ada kemungkinan untuk menerapkan hasil penelitian terebut, maka peneliti dalam membuat laporannya harus memberikan uraian yang rinci, jelas, sistimatis, dan dapat dipercaya. Dengan demikian maka pembaca menjadi jelas atas hasil penelitian tersebut. Sehingga dapat memutuskan dapat atau tidaknya untuk mengaplikasikan hasil penelitian tersebut ditempat lain.
3. Ketergantungan (dependability)

Uji dependability dilakukan dengan melakukan audit terhadap keseluruhan proses penelitian. Untuk itu pengujian dependability dilakukan dengan cara melakukan audit terhadap keseluruhan proses penelitian. Caranya dilakukan oleh auditor yang indipenden, atau pembimbing untuk mengaudit keseluruhan aktifitas penelitian dalam melakukan penelitian. Bagaimana peneliti memulai menentukan masalah/fokus, memasuki lapangan, menentukan sumber data, melakukan analisis data, melakukan uji keabsahan data, sampai membuat kesimpulan harus dapat ditunjukkan oleh peneliti. Jika peneliti tak mempunyai dan tak dapat menunjukkan “ jejak aktifitas lapangannya” maka dependability penelitiannya patut diragukan.

\section{Kepastian (konfirmability)}

Uji konfirmability mirip dengan uji dependability, sehingga pengujiannya dapat dilakukan secara bersamaan. Menguji Konvirmability berarti menguji hasil penelitian, dikaitkan dengan proses yang dilakukan, maka peneliti tersebut telah memenuhi standar konfirmability. Dalam penelitian, jangan sampai proses tidak ada, tetapi hasilnya ada.

\section{HASIL PENELITIAN}

\section{A. Gambaran Umum Objek Penelitian}

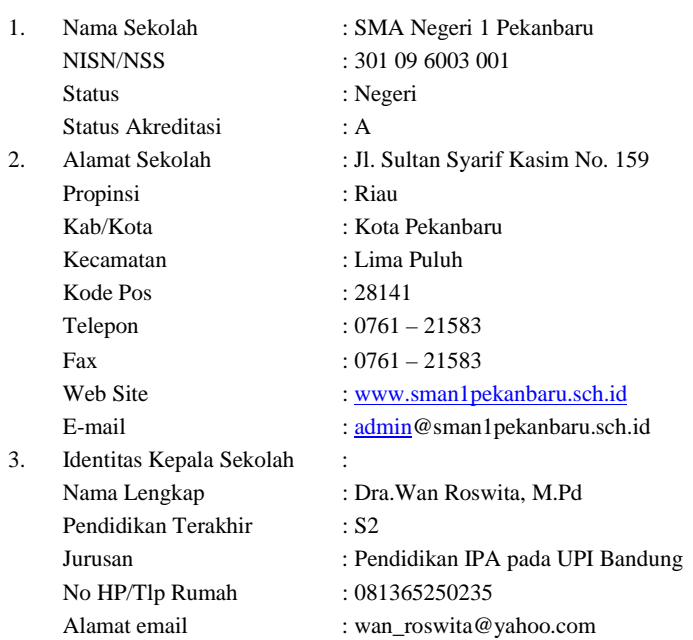


B. Temuan Penelitian

Sub Fokus 1: Pencapaian Visi dan Pelaksanaan Misi Program PIK R SMAN 1 Pekanbaru

Berdasarkan hasil penelitian menunjukkan bahwa terdapat 3 aspek dari 5 aspek yang telah memenuhi standar objektif atau berada pada kriteria sedang.

Visi PIK-R SMAN 1 Pekanbaru

“ Menjadikan siswa-siswi SMA Negeri 1 Pekanbaru yang kuat dan tangguh dalam menghadapi arus perubahan zaman serta memperlengkapi diri dengan sikap dan pengutahuan yang benar tentang remaja dan permasalahannya”

Misi PIK-R SMAN 1 Pekanbaru

1. Memberikan pelatihan dan seminar kepada pendidik dan konselor sebaya tentang PIKR secara berkala

2. Merencanakan dan melaksanakan program pelayanan terpadu kepada siswa-siswi yang menghadapi permasalahan seputar remaja

3. Melaksanakan kegiatan kerjasama dengan jaringan kemitraan untuk memperluas dampak positif PIK-R kepada siswa-siswi diluar lingkungan sekolah.

Sub Fokus 2 : Perencanaan ( Planning) PIKR SMAN 1 Pekanbaru

Perencanaan menurut Akdon (2011:114) perencanaan pendidikan dibuat secara fleksibel dan tidak kaku, mengikuti perkembangan zaman dan perubahan situasi dan kondisi, sehingga pelaksanaannya tidak terjebak dalam suatu keadaan yang statis. Kurikulum didesain sedemikian rupa, yang secara filosopis merupakan hakikat pendidikan.

Berdasarkan hasil penelitian menunjukan bahwa terdapat 4 aspek dari 5 aspek yang telah memenuhi standar objektif atau pada kreteria baik

Sub fokus 3: Pengorganisasian (Organizing) program PIK-R di SMA Negeri 1 Pekanbaru.

Berdasarkan hasil penelitian menunjukan bahwa terdapat 5 aspek dari 5 aspek kriteria pencapaian yang telah memenuhi standar objektif atau pada kreteria sangat baik. pengorganisasian merupakan fungsi kedua dari fungsi manajemen setelah perencanaan. Hal tersebut dilakukan untuk menetapkan siapa saja yang terlibat dan memiliki kewenangan pada struktur organisasi sekolah pada PIK-R SMAN 1 Peknbaru. Organisasi menurut Akdon(2011:177) organisasi sebagai gabungan orang-orang yang bekerja sama dalam suatu pembagian kerja untuk mencapai tujuan bersama. Dalam organisasi terdapat susunan orang yang diberi tugas dan wewenang yang berbeda-beda yang disebut dengan struktur organisasi. Garis hirarkisnya menunjukan jabatan, tugas, dan wewenang masing-masing, tetapi dalam pelaksanaan program organisasi selalu ada hubungan fungsional organisasi.

\section{Sub fokus 3: Pelaksanaan (actuating) Program PIK-R SMAN 1 Pekanbaru \\ Pelaksanaan (Actuating) menurut Wibowo} (2012:14) actuating berkenaan dengan fungsi manajer untuk menjalankan tindakan dan melaksanakan pekerjaan yang diperlukan untuk mencapai tujuan yang ingin dicapai oleh organisasi. Actuating merupakan implikasi dari apa yang direncanakan dalam fungsi planning dengan memanfaatkan persiapan yang sudah dilakukan dalam orgnizing

Berdasarkan hasil penelitian menunjukan bahwa terdapat 4 aspek dari 5 aspek kriteria pencapaian yang telah memenuhistandar objektif atau pada kriteria baik. Pelaksanaan merupakan fungsi ketiga dari fungsi manajemen setelah pengorganisasian.

\section{Sub fokus 4: Pengawasan ( controlling) Program PIK-R SMAN 1Pekanbaru}

Pengawasan (controlling)) menurut Wibowo (2012:14) controlling merupakan ativitas untuk meyakinkan bahwa semua hal berjalan seperti seharusnya dan memonitor kenerja organisasi. Kinerja aktual harus dbandingkan dengan tujuan yang ditetapkan yang ditetapkan sebelumnya. Jika terdapat deviasi signifikan, dilakukan koreksi dan dikembalikan kejalur yang tepat. Dengan 
demikian controlling melakukan koreksi terhadap pelaksanaan dan untuk mengetahui apakah tujuan dapat dicapai.

\section{Sub fokus 5: Hasil Program PIK-R SMAN 1 Pekanbaru}

Berdasarkan hasil penelitian menunjukan bahwa terdapat 2 aspek dari 5 aspek kriteria pencapaian yang telah memenuhi standar objektif atau pada kategori kriteria kurang

Dari hasil wawancara untuk hasil pada PIK-R SMAN 1 Pekanbaru dari beberapa orang yang di wawancarai menyatakan hal yang hampir serupa. Sebagaimana wawancara yang di lakukan dengan Siswa Sri Intan Agusmai Selasa 25 April 2017 Jam 13.00 : Hasil yang dicapai dalam pelaksanaan program PIK- $R$ SMAN 1 Pekanbaru melalui kegitan ekstrakulikuler yaitu dapat bekerja sama dengan pihak-pihak lain yaitu UPTD puskemas lima puluh, BKKBN,BNN dll, dapat mengadakan evaluasi program PIK-R. SMAN 1 Pekanbaru. PIK-R belum banyak mendapatkan prestasi.

\section{SIMPULAN DAN SARAN}

Berdasarkan hasil penelitian yang dilakukan secara kualitatif maka dapat disimpulkan bahwa:

1) Pada subfokus pertama yaitu pencapaian Visi dan pelaksanaan misi Program PIK-R SMAN 1 Pekanbaru dikategorikan sedang karena terpenuhi 3 poin yaitu (1) Visi misi terprogram (2) memiliki izin pelaksanaan program PIK-R (5) Kerja sama sekolah dan lembaga lain. Pada subfokus ini 2 poin tidak terpenuhi yaitu pada poin (3) Kegiatan terlaksana tepat waktu dan poin (4) sarana dan prasarana lengkap. Berdasarkan hasil temuan yaitu hasil observasi dan wawancara dari informan waktu ekstrakulikuler PIK-R yang telah disepakati terkadang tidak terlaksana karena terpakai untuk kegiatan lainnya. Sarana prasarana penunjang PIKR SMA Negeri 1 Pekanbaru belum semuanya terpenuhi.

2) Program PIK R. Subfokus kedua ini pada perencanaan poin yang tidak terpenuhi yaitu poin (2) kurikulum berjalan sesuai rencana. Berdasarkan hasil temuan dokumentasi dan wawancara pada informan Sebagaimana yang disampaikan oleh informan perencanaan program PIK-R melalui kegiatan ekstrakurikuler sudah baik, sudah mempunyai perencanaan dalam bentuk dokumen, program yang sudah direncanakan nyata dilakukan dan kurikulum belum berjalan sesuai perencanaan, pengelolaan sarana dan prasarana sudah baik dan sumber daya paham tentang pengelolaan program PIK-R.

3) Pada sub fokus ke tiga Pengorganisasian PIK-R di SMAN 1 Pekanbaru diketegorikan sangat baik karena terpenuhi 5 poin yaitu (1) Manajer Dikepalai oleh Kepala sekolah. (2) Mempunyai struktur Organisasi terdiri dari Ketua, sekretaris Bendahara dan devisi-devisi meliputi devisi SDM, Devisi komunikasi, layanan konsultasi, seni, keagamaan dll. (3) Guru pembimbing memiliki kemampuan Mengelola PIK R (4) Pembagian tanggung jawab berdasarkan rapat anggota. (5) Segala tugas, tanggung jawab dan wewenang tertuang dalam struktur organisasi. Berdasarkan sebagaimana wawancara yang di lakukan dengan informan yaitu dalam pengorganisasian PIK-R di SMAN 1 Pekanbaru sudah sangat baik karena dalam pelaksanaannya diketahui kepala sekolah, dalam kepengurusan PIK-R sudah ada ketua, sekretaris, bendahara, serta dibantu dengan beberapa devisi untuk mendukung program PIK-R, guru pembimbing yang ada sudah memiliki kemampuan mengelola PIK$\mathrm{R}$ dan pembagian tanggung jawab sudah berdasarkan rapat anggota, semua melaksanakan tugas dan tanggung jawabnya sesuai dengan jabatan yang dipegang dalam organisasi PIK-R yang ada disekolah.

4) Pada subfokus keempat Pelaksanaan PIKR di SMAN 1 Pekanbaru diketegorikan baik karena terpenuhi 4 poin yaitu: (1) Memiliki rencana kegiatan (2) Melakukan pertemuan rutin penyampaian materi oleh 
pembina PIK R SMAN 1 atau sharingn pengalaman. (4) Kegiatan Program PIK R dilakukan diluar PBM, bekerja sama dengan institusi pendidikan kesehatan seperti kedoteran, keperawatan, kebidanan, BKKBN, BNN,dll. (5) Mengikuti lombalomba tingkat sekolah/Nasional yang berkaitan dengan kesehatan reproduksi. Subfokus ketiga ini pada perlaksanan poin yang tidak terpenuhi yaitu poin (3). Melakukan konseling melalui tatap muka, SMS, Line, Dll. Berdasarkan hasil temuan dokumentasi dan wawancara oleh informan. Pelaksanaan program PIK-R sudah baik karena memiliki rencana kegiatan yang dibuat setiap tahunnya. Dan pertemuan rutin PIK-R setiap minggunya dihari sabtu dimana pematerinya adalah pembin PIR-R, sharing pengalaman dilaksanakan diluar PBM. Anggota PIK-R SMAN 1 Pekanbaru ikut berpartisipasi dalam mengikuti lomba-lomba tingkat sekolah/nasional. Untuk melakukan konseling melalui tatap muka belum berjalan seperti yang diharapkan.

5) Pada subfokus kelima Pengawasan PIK-R di SMAN 1 Pekanbaru kategori sedang karena memenuhi 3 poin yaitu: poin (1) Pengontrolan dilakukan Pembina PIK R secara rutin setiap minggu.(2) Interaksi antara Pembina, guru BK dan Koordinator PIK-R membahas yang menjadi hambatan dalam pelaksanaan PIK R (4) Rapat kerja setiap bulan kepala sekolah, Pembina PIK R dan Guru BK. Subfokus ketiga ini pada pengawasan poin yang tidak terpenuhi yaitu poin (3). Pengontrolan dilakukan kepala sekolah secara sembunyi dan poin (5) Interaksi kepala sekolah dan siswa untuk melihat kinerja pembina, dan guru BK belum berjalan seperti yang diharapkan. Berdasarkan hasil wawancara dengan informan yaitu: Pengawasan Program PIKR di SMAN 1 Pekanbaru kategori sedang dimana pengontrolan dilakukan pembina PIK-R secara rutin setiap minggu telah berjalan, Interaksi antara pembina, guru BK dan koordinator PIK-R membahas yang menjadi hambatan dalam pelaksanaan PIK$\mathrm{R}$ telah berjalan, dan Rapat kerja setiap bulan kepala sekolah, pembina PIK-R dan guru BK sudah berjalan. Yang belum berjalan pengontrolan dilakukan secara sembunyi dan interaksi kepala sekolah dan siswa dan melihat kinerja pembina, dan guru BK belum berjalan seperti harapan.

6) Pada subfokus keenam mengenai Hasil yang telah dicapai PIK-R di SMAN 1 Pekanbaru kategori kurang karena memenuhi 2 kriteria yaitu poin (1) Mengevaluasi pelaksanaan program PIK R dan poin (5) Bekerja sama dan mendapat penghargaan dari pihak-pihak lain seperti BKKBN, BNN dll. Sedangkan untuk poin (2) Mendapat kejuaraan/ pertandingan ditingkat kota, propinsi atau Nasional PIK-R yang berhubungan dengan kesehatan (3) Kreatifitas siswa memiliki nilai jual dan (4) Menghasilkan karya yang inovatif belum mendapatkan hasil yang diharapkan. Sebagaimana wawancara yang di lakukan dengan informan yaitu: hasil dalam pelaksanaan program PIK-R SMAN 1 Pekanbaru melalui kegitan ekstrakulikuler termasuk dalam kategori kurang karena hanya 2 aspek yang tercapai yaitu mengevaluasi pelaksanaan PIK-R dan Bekerja sama dan mendapat penghargaan dari pihak-pihak lain seperti BKKN, BNN dll.

\section{DAFTAR PUSTAKA}

BKKBN, (2016). Pedoman Pengelolaan Pusat Informasi dan Konseling Remaja dan Mahasiswa (PIK-R/M), Jakarta: Direktorat Bina Ketahanan Remaja.

BKKBN, (2012). Pedoman Pengelolaan Pusat Informasi dan Konseling Remaja dan Mahasiswa ( PIK-R/M), Jakarta: Direktorat Bina Ketahanan Remaja.

dan Modul Pelatihan Program Penyiapan Kehidupan Berkeluarga Bagi Remaja ( PKBR): Jakarta. 
Elizabeth B. Hurlock,(2002). Psikologi Perkembangan Suatu Pendekatan Sepanjang Rentang Kehidupan, Jakarta: Erlangga.

Fitri R.Ghozali, (2007). Memahami Perkembangan Psikologi Remaja. Jakarta: Prestasi Pustakaraya.

Hikmat, (2009). Manajemen Pendidikan. Bandung: CV Bumi Aksara.

Husaini Usman, (2013). Manajemen Teori, Praktik, dan Riset Pendidikan. Jakarta: PT Bumi Aksara.

Lexy J. Moleong, (2012). Metodologi Penelitian Kuantitatif. Bandung: PT. Remaja Rosdakarya.

M.Burhan Bungin, (2012). Penelitian Kualitatif. Jakarta: Fajar Interpratama Offset.

Sugiono, (2012). Metode Penelitian Pendidikan Pendekatan Kuantitatif, Kualitatif, dan R \& G. Bandung: Alfabeta.
T.Hani Handoko, 1999. Manajemen. Yogyakarta. BPFE- Yogyakarta.

Wibowo, 2012. Manajemen Perubahan. Jakarta. PT. Raja Grafindo Persada.

Permendiknas. Undang-undang No.22 Tahun 2003, Pasal 3. standar Nasional Pendidikan. Depdiknas

Ricky Arnold Nggili.,2011. dalam Pelatihan kepemimpinan Fakultas Teknologi Informatika - UKSW.( On-line). rickyanggili.blogspot.co.id/2011/11/ poac-planning-organizingactuating.html.Diakses 17 November 2016.

, (2015) pengertian p.o.a.c dalam ilmu manajemen lengkap.(On-line) http:// hakikatbisnis.blogspot.co.id/2015/06/ pengertian poac dalam ilmumanajemen lengkap.html. Diakses 17 November 2016. 